\title{
Christians in the Middle East: A New Subfield? Fiona MCCALlum
}

School of International Relations, University of St. Andrews, St. Andrews, Scotland; e-mail: fm25@st-andrews.ac.uk

doi:10.1017/S0020743810000498

The topic of Christians in the Middle East appears to be enjoying a growing vitality within Middle East studies. This is not to say that scholarship ignored the subject in the past, but it was rarely seen as an independent area of study. Works tended to focus on the historical origins, faith, and rites of the different churches within Eastern Christianity. ${ }^{1}$ Those that looked specifically at Christian communities tended to concentrate on their relations with other groups, especially in the context of a minority framework. ${ }^{2}$ Some interdisciplinary volumes such as those edited by Andrea Pacini and Anthony O'Mahony moved beyond this limited approach to cover a wider range of issues, but several of the contributions retained this descriptive tendency rather than relating directly to theoretical debates within different disciplines. ${ }^{3}$

Looking specifically at scholarship on the Maronite Church and community in Lebanon, one can see a pattern that is being repeated in other case studies of Christians and Christianity in the Middle East. Discussion on the Maronites has tended to be understandably linked to the civil war and its implications for the Lebanese confessional system. ${ }^{4}$ In terms of exploring the role of Christian institutions in Lebanon, most notably, the Maronite patriarchate, the main source has been David Kerr's unpublished PhD dissertation. ${ }^{5}$ This work examines in detail the political role of the patriarchs. The same theme is pursued by Elizabeth Picard, who connects this role to the $z u^{\prime} a m \bar{a}^{\text {' (traditional }}$ communal leaders) of the Lebanese political system. ${ }^{6}$ This focus on church leadership started to gain momentum among those studying the patriarchal churches in the region, and several recent works examine the churches as social and political institutions. ${ }^{7}$ An analysis of the political role of current Patriarch Nasrallah Sfeir has been undertaken in my own work and that of Jehan al-Awit Adwan. ${ }^{8}$ New interpretations of the impact of the civil war on the church are also being produced. ${ }^{9}$ Such studies examine an important actor in Lebanese politics that has usually been overlooked in favor of state-centric approaches or concentration on Islamist movements. This, in turn, has masked internal divisions within the Christian community and attempts to bridge them, which can have a significant impact on Lebanese politics, influencing, for example, the presidential vacancy in 2008 and the difficulties in forming a cabinet in 2009.

By examining Christian communities in the Middle East, scholarship can contribute to existing debates and introduce new research topics. As Paul Rowe argues in his roundtable essay, there is much more awareness of the "agency" factor. Through exploring internal developments and external interactions, the study of Christian communities not only provides insight into specific groups in the Middle East but also allows comparisons to be made with the Muslim majority. Issues that are traditionally seen as exclusively Islamic in origin can be shown to have a wider impact, thus raising questions regarding the role of political and cultural developments in the region. These might include the political involvement of religious communities and institutions or social issues such as the impact of globalization and the growth of diaspora communities. For 
example, Geraldine Chatelard and Annika Rabo demonstrate that tribal structures and family law have similar effects on Christian and Muslim communities, and both Paul Rowe and I have explored the role of technology and the diaspora in heightening existing tension between Muslim and Christian communities in Egypt. ${ }^{10}$

The study of Christians in the Middle East also encourages deeper interdisciplinary collaboration. This has a dual purpose of producing a rich body of work that covers multiple perspectives and raising new issues to be considered in each core discipline. A recent workshop held by the Christians in the Middle East Research Network included participants from the fields of political science, international relations, history, sociology, anthropology, and theology as well as those from Middle East and Islamic studies. ${ }^{11}$ Although it is important to build up this field expertise, it is also imperative that an exclusive approach is not adopted. Rowe and Heyberger remark in their essays that little of this scholarship is published in mainstream Middle East journals or indeed major disciplinary ones. Recent publications indicate that editors are increasingly conducive to such research topics if given the opportunity. It is clear that we need to redress the gaps relating to Christians in the Middle East, but this is best done by connecting our work to wider topics such as minorities, religion and politics, and democratization. Edited books focusing specifically on Christianity in the region are of course essential resources, but these need to be supplemented by a presence in mainstream journals. The growing interest in the communities in question noted by Rowe and Heyberger is also one that needs to be engaged by all scholars working in this field. In my own area of interest-religion and politics_-scholarship by authors from the region is scarcer than in other fields. This is partially attributable to not only the sensitive nature of the topic but also difficulties in convincing academic elites in the region that it is a worthwhile area of interest. It is clear that a severe gap exists in this respect, and it is hoped that networks such as the Christians in the Middle East Research Network can help connect scholars. To conclude, the burgeoning research field of Christianity and Christians in the Middle East is gaining recognition as an area of new interdisciplinary research that adds to existing knowledge and approaches to the region and raises questions as to how we interpret developments. The next step is to build on this promising start and retain its relevance to wider research both within the field of Middle East studies and individual disciplines.

\section{NOTES}

${ }^{1}$ See Robert Brenton Betts, Christians in the Arab East (London: Society for Promoting Christian Knowledge, 1979); Bruce Masters, Christians and Jews in the Ottoman Arab World: The Roots of Sectarianism (Cambridge: Cambridge University Press, 2001); and Otto Meinardus, Two Thousand Years of Coptic Christianity (Cairo: American University in Cairo Press, 1999).

${ }^{2}$ See Ofra Bengio and Gabriel Ben-Dor, eds., Minorities and the State in the Arab World (Boulder, Colo.: Lynne Rienner, 1999).

${ }^{3}$ See Andrea Pacini, ed., Christian Communities in the Arab Middle East: The Challenge of the Future (Oxford: Clarendon Press, 1998); Anthony O'Mahony, ed., Christianity in the Middle East: Studies in Modern History, Theology and Politics (London: Melisende, 2008); and Anthony O'Mahony and Emma Loosley, eds., Eastern Christianity in the Modern Middle East (London: Routledge, 2010).

${ }^{4}$ Charles Winslow, Lebanon: War and Politics in a Fragmented Society (London: Routledge, 1996) and Theodor Hanf, Coexistence in Wartime Lebanon (London: Centre for Lebanese Studies, 1993). 
${ }^{5}$ David Kerr, "The Temporal Authority of the Maronite Patriarchate, 1920-1958: A Study in the Relationship of Religious and Secular Power" (PhD diss., University of Oxford, 1973).

${ }^{6}$ Elizabeth Picard, "The Dynamics of the Lebanese Christians: From the Paradigm of the Ammiyyat to the Paradigm of Hwayyek," in Christian Communities in the Arab Middle East, ed. Pacini, 200-21.

${ }^{7}$ S. S. Hasan, Christians versus Muslims in Modern Egypt: The Century-Long Struggle for Coptic Equality (New York: Oxford University Press, 2003) and Anthony O'Mahony, "Patriarchs and Politics: The Chaldean Catholic Church in Modern Iraq," in Christianity in the Middle East, ed. O'Mahony, 105-42.

${ }^{8}$ Fiona McCallum, "The Political Role of the Patriarch in the Contemporary Middle East," Middle Eastern Studies 43 (2007): 923-40; and Jehan al-Awit Adwan, "L'action politique et diplomatique du Siege, Maronite de Bkerke sous le patriarcat de Nasrallah Boutros Sfeir" (PhD diss., Institut d'etudes Politiques de Paris, 2006).

${ }^{9}$ Alexander Henley, "Politics of a Church at War: Maronite Catholicism in the Lebanese Civil War," Mediterranean Politics 13 (2008): 353-69.

${ }^{10}$ Geraldine Chatelard, Briser la mosaique: Lien social et identites collectives chez les chrétiens de Madaba, Jordanie, 1870-1997 (Paris: Editions du CNRS, 2004); Annika Rabo, "Legal Pluralism and Family Law in Syria," in The Governance of Legal Pluralism, ed. Werner Zips and Markus Weilenmann (Münster, Germany: Lit-Verlag, forthcoming); Paul Rowe, "Neo-Millet Systems and Transnational Religious Movements: The Humayun Decrees and Church Construction in Egypt," Journal of Church and State 49 (2007): 329-50; and Fiona McCallum, "Religious Diaspora and Information Communications Technology: The Impact of Globalization on Communal Relations in Egypt," in The New Arab Media: Technology, Image and Perception, ed. Mahjoob Zweiri and Emma C Murphy (London: Ithaca Press, 2010).

${ }^{11}$ Christians in the Middle East Research Network, www.cme.stir.ac.uk (accessed 8 February 2010). 